\title{
Krill-copepod interactions at South Georgia, Antarctica, I. Omnivory by Euphausia superba
}

\author{
A. Atkinson*, R. Snÿder \\ British Antarctic Survey, Natural Environment Research Council, High Cross, Madingley Rd, \\ Cambridge CB3 0ET, United Kingdom
}

\begin{abstract}
Feeding by juvenile Antarctic krill Euphausia superba near South Georgia was assessed during the austral summer of 1995/1996. Gut fluorescence results were compared with those from incubatıons in natural seawater and seawater enriched with phytoplankton and zooplankton. In natural seawater, with typically low food concentrations (median $56 \mathrm{mg} \mathrm{C} \mathrm{m}^{-3}$ ) the median ration was $0.68 \%$ of krill carbon $\mathrm{d}^{-1}$. Phytoplankton dominated carbon in the natural incubation water but dinoflagellates, ciliates and small calanoid copepods dominated the carbon intake of krill. In both natural and enriched water, maximum clearance rates were on 1 to $3 \mathrm{~mm}$ calanoid copepods. Copepods larger than this (e.g late copepodite stages of Calanoides acutus and Rhincalanus gigas) were cleared more slowly despite dominating the carbon in the enriched incubations. Oithona spp. were cleared more slowly than calanoids of similar size, despite their greater abundance and their similar contributions to available carbon. These trends could reflect detection/escape interactions between krill and copepods. With enriched food, copepods dominated krill dict, krill rations exceeded $10 \%$ of body carbon $\mathrm{d}^{-1}$ and rations did not appear to reach a plateau even at food concentrations of $\sim 1 \mathrm{~g} \mathrm{C} \mathrm{m}^{-3}$ This suggests that krill could feed rapidly during periodic encounters with layers or patches of zooplankton. Gut fluorescence revealed gut passage times of 3.7 to $6.3 \mathrm{~h}$ and an algal carbon ration of $0.43 \% \mathrm{~d}^{-1}$, thus supporting the low algal carbon rations derived from the incubations. Published acoustic values of mean krill biomass north of South Georgia that summer of $8.3 \mathrm{~g}$ dry mass $\mathrm{m}^{-2}$ were combined with their clearance rates to give estimates of krill removing daily $0.2 \%$ of phytoplankton standing stocks, $0.6 \%$ of protozoans and $1.6 \%$ of small calanoid copepods. This impact on copepods is much higher than previous estimates from Antarctic amphipods and chaetognaths. The long generation times of Antarctic copepods mean that krill were potentially important predators of small copepods during our study.
\end{abstract}

KEY WORDS: Antarctic krill - Euphausia superba - Feeding - Predation - Diet - Copepods - Southern Ocean . South Georgia

\section{INTRODUCTION}

Euphausia superba is an important component of the Antarctic food web (Hopkins \& Torres 1989, Hopkins et al. 1993), especially in food chains of commercial importance (Everson \& Goss 1991). However knowledge of its feeding ecology is still incomplete and sometimes contradictory (see Quetin et al. 1994). Most euphausiids are omnivorous (Mauchline 1980, Sameoto 1980) and although this is true for E. superba (herafter 'krill'), its mouthparts seem well adapted for eating phytoplankton (Nemoto 1967, Kils 1983, MC-

·E-mail: a.atkinson@bas.ac.uk
Clatchie 1985). The seasonal importance of carnivory relative to herbivory for krill has not been quantified, despite a series of studies showing that it eats phytoplankton (e.g. Antezana \& Ray 1984, Hopkins et al. 1993), protozoans (Froneman et al. 1996) and metazoans (Boyd et al. 1984, Hopkins et al. 1993). During summer around South Georgia, phytoplankton intake alone could not meet the estimated respiratory costs of krill (Pakhomov et al. 1997). This and the presence of metazoans in their guts led these authors to suggest that, outside of bloom periods, zooplankton could form a significant part of krill diet.

For euphausiids in general, some basic questions remain on their carnivorous feeding. Very little is 
known either of the spectrum of zooplankton taxa which they can eat (Barange et al. 1991) or of their functional responses (Ohman 1984, Price et al. 1988, Pilditch \& McClatchie 1994). For krill in particular, their swarming behaviour and frequently high biomass mean that such studies are germane, both to the nutrition of krill and to their local impact on prey populations.

This study was prompted by an unusually high krill abundance and low copepod abundance during our 1995/1996 South Georgia field season (our unpubl. data) plus the knowledge that krill can feed efficiently on copepods (Price et al. 1988, Granéli et al. 1993). To compare the feeding rates of juvenile krill on a spectrum of particles ranging from picoplankton to $10 \mathrm{~mm}$ copepods, we incubated krill in both natural seawater and enriched food assemblages. Gut fluorescence/gut evacuation experiments provided a complementary indication of the importance of phytoplankton in their diet. An acoustic estimate of krill biomass near South Georgia was then combined with our feeding results to estimate the impact of krill on their prey.

\section{METHODS}

Incubation experiments. These experiments were done aboard RRS 'James Clark Ross' in austral mid. summer (January/February 1996) from shelf and oceanic locations north of South Georgia (Table 1). Juvenile krill were usually obtained from slow $(-0.2 \mathrm{~m}$ $\mathrm{s}^{-1}$ ) vertical hauls in the topmost $100 \mathrm{~m}$ with a $200 \mu \mathrm{m}$ Bongo net with a solid cod end. Occasionally they were collected from night-time hauls with a neuston net, which was towed at 1 to 2 knots along the surface. Healthy and undamaged krill were maintained in $50 \mathrm{I}$ holding buckets in the ship's cold room to acclimate prior to experiments. The cold room was set at the approximate temperature of the mixed layer; normally $2^{\circ} \mathrm{C}$ but at $5^{\circ} \mathrm{C}$ for 4 experiments with krill from near the Polar Front. Acclimation times varied (Table 1), but $-90 \%$ of the water in the holding containers was changed daily.

The krill feeding incubations were in cylindrical 561 polyethylene carboys, of diameter $26 \mathrm{~cm}$ and depth $55 \mathrm{~cm}$. Krill tend to behave abnormally in small con-

Table 1. Summary of the 13 krill feeding experiments. Chl a and carbon concentrations refer to values in the final control carboys of each experimental pair, except values with an asterisk, which are values for separate initial carboys. Carbon concentrations are derived from microplankton $>5 \mu \mathrm{m}$ plus all metazoans smaller than Rhincalanus giga CV. Values in bold italics are for ambient seawater and the others are for seawater enriched with phytoplankton and zooplankton. N/A: not analyzed

\begin{tabular}{|c|c|c|c|c|c|c|c|c|c|}
\hline $\begin{array}{l}\text { Expt } \\
\text { no. }\end{array}$ & $\begin{array}{l}\text { Date } \\
\text { (1996) }\end{array}$ & Location & $\begin{array}{l}\text { Chl a } \\
\text { concentration } \\
\left(\mathrm{mg} \mathrm{m}^{-3}\right)\end{array}$ & $\begin{array}{l}\text { Carbon } \\
\text { concentration } \\
\left(\mathrm{mg} \mathrm{m}^{-3}\right)\end{array}$ & $\begin{array}{l}\text { Mean krill } \\
\text { dry mass } \\
\text { (mg) }\end{array}$ & $\begin{array}{l}\text { No. of } \\
\text { krill per } \\
\text { carboy }\end{array}$ & $\begin{array}{c}\text { Krill } \\
\text { C conc. } \\
\left(\mathrm{mg} \mathrm{m} \mathrm{m}^{-3}\right)\end{array}$ & $\begin{array}{l}\text { Acclimation } \\
\text { period } \\
\text { (d) }\end{array}$ & $\begin{array}{c}\text { Duration } \\
\text { of expt } \\
\text { (h) }\end{array}$ \\
\hline 1 & 9 Jan & $\begin{array}{l}52^{\circ} 12^{\prime} \mathrm{S} \\
40^{\circ} 02^{\prime} \mathrm{W}\end{array}$ & $\begin{array}{llll}0.89 & 2.1 & 4.8 & 12\end{array}$ & $\begin{array}{llll}54 & 166 & 395 & 854\end{array}$ & 96 & 9 & 6171 & 2 & 14 \\
\hline 2 & $11 \mathrm{Jan}$ & $\begin{array}{l}54^{\circ} 06^{\prime} \mathrm{S}_{1} \\
36^{\circ} 32^{\prime} \mathrm{W}\end{array}$ & $\begin{array}{lll}0.91 & 0.93 & 9.2\end{array}$ & $\begin{array}{lll}52 & 81 & 156\end{array}$ & 96 & 8 & 5485 & 4 & 7 \\
\hline 3 & $13 \mathrm{Jan}$ & $\begin{array}{l}53^{\circ} 00^{\prime} \mathrm{S} \\
35^{\circ} 27^{\prime} \mathrm{W}\end{array}$ & $\begin{array}{llll}1.4 & 1.7 & 2.0 & 3.9\end{array}$ & $\begin{array}{llll}73 & 153 & 314 & 751\end{array}$ & 96 & 8 & 5485 & 6 & 10 \\
\hline 4 & 15 Jan & $\begin{array}{l}54^{\circ} 15^{\prime} \mathrm{S} \\
34^{\circ} 26^{\prime} \mathrm{W}\end{array}$ & $1.73 .7 \quad 6.4$ & 87253446 & 24 & 27 & 4543 & 1 & 12 \\
\hline 5 & $17 \operatorname{Jan}$ & $\begin{array}{l}54^{\circ} 02^{\prime} \mathrm{S}_{1} \\
36^{\circ} 33^{\prime} \mathrm{W}\end{array}$ & $\begin{array}{llll}0.76 & 0.71 & 1.7 & 7.9\end{array}$ & $\begin{array}{llll}43 & 50 & 203 & 1164\end{array}$ & 24 & 32 & 5485 & 3 & 6 \\
\hline 6 & $19-20 \mathrm{Jan}$ & $\begin{array}{l}53^{\circ} 24^{\prime} \mathrm{S} \\
38^{\circ} 14^{\prime} \mathrm{W}\end{array}$ & $\begin{array}{lllll}1.6 & 1.7 & 2.0 & 2.3\end{array}$ & $85 \quad 107 \quad 202 \quad 342$ & 24 & 30 & 5143 & 5 & 7 \\
\hline 7 & $21 \mathrm{Jan}$ & $\begin{array}{l}53^{\circ} 45^{\prime} \mathrm{S} \\
38^{\circ} 23^{\prime} \mathrm{W}\end{array}$ & $0.93 \quad 1.3 \quad 2.4$ & $\begin{array}{lll}56 & 102 \quad 405\end{array}$ & 23 & 10 & 2025 & 1 & 10 \\
\hline 8 & $23 \mathrm{Jan}$ & $\begin{array}{l}53^{\circ} 52^{\prime} \mathrm{S} \\
38^{\circ} 45^{\prime} \mathrm{W}\end{array}$ & N/A N/A & 571581 & 25 & 6 & 1071 & 3 & 20 \\
\hline 9 & $29 \mathrm{Jan}$ & $\begin{array}{l}53^{\circ} 02^{\prime} \mathrm{S} \\
39^{\circ} 20^{\prime} \mathrm{W}\end{array}$ & $0.892 .0 \mathrm{~N} / \mathrm{A}$ & $\begin{array}{lll}78 & 169 & 523\end{array}$ & 108 & 9 & 7200 & 0.5 & 5 \\
\hline 10 & $31 \mathrm{Jan}$ & $\begin{array}{l}53^{\circ} 20^{\prime} \mathrm{S} \\
47^{\circ} 25^{\prime} \mathrm{W}\end{array}$ & 0.75 & 41 & 108 & 3 & 2314 & 2 & 20 \\
\hline 1.1 & 15 Feb & $\begin{array}{l}49^{\circ} 45^{\prime} \mathrm{S} \\
41^{\circ} 26^{\prime} \mathrm{W}\end{array}$ & $0.32 * 0.29 * 0.31 \quad 0.29$ & $27^{\prime} 25^{*} 2928$ & 112 & 2 & 1628 & 0.25 & 23 \\
\hline 12 & 17 Feb & $\begin{array}{l}50^{\circ} 32^{\prime} S_{1} \\
39^{\circ} 47^{\prime} W\end{array}$ & $1.5 \cdot 1.5 \cdot 1.41 .3$ & $120^{\circ} 124^{\circ} 109108$ & $8 \quad 114$ & 2 & 1216 & 2 & 24 \\
\hline 13 & 22 Feb & $\begin{array}{l}53^{\circ} 53^{\prime} \mathrm{S}_{1} \\
38^{\circ} 38^{\prime} \mathrm{W}\end{array}$ & $1.0^{*} 1.0^{*} 1.1 \quad 1.0$ & $56^{*} 57^{*} 58 \quad 55$ & 23 & 5 & 994 & 1 & 23 \\
\hline
\end{tabular}


tainers (Price et al. 1988, Quetin et al. 1994) but this size was chosen as the largest liftable and replicable aboard ship. Also the krill were 25 to $40 \mathrm{~mm}$ juveniles, so their length relative to that of the container is less than for adults in a similar volume (Price et al. 1988) For a typical experiment, an enriched krill food source was obtained from 1 or more slow tows with a $100 \mu \mathrm{m}$ Bongo net from the top $100 \mathrm{~m}$ layer. The net frame had a spring-loaded motion compensating device, designed to adjust for the rolling of the ship, smoothing the net trajectory and thus minimising abrasion of the catch. This worked well and the zooplankton were generally in excellent condition, often with intact setulation and active escape responses. These net catches were first diluted to $\sim 40 \mathrm{l}$ with surface seawater and then screened by decanting beakerfuls and removing chaetognaths and large predatory copepods (chiefly CIV to CVI of Euchaeta spp.).

The incubation water was collected with a plastic bucket over the side of the ship. The use of a bucket to collect this quantity of seawater rather than the ship's 'non toxic' supply, as well as our use of a motion compensating net, were in order to obtain a food assemblage which was as undamaged as possible, and thus fully capable of escape responses. Surface seawater was transferred rapidly to a $30 \mathrm{l}$ bucket, from which silicon tubes siphoned it simultaneously into either six or eight 561 carboys. These were transforred to the cold room and left for 1 to $2 \mathrm{~h}$ to stabilise the food medium (Gifford 1993)

Each experiment was set up by dividing the carboys into 3 or 4 pairs. One of the pair contained krill and the other served as a control without krill. In all experiments except Expt 8, at least 1 of the carboy pairs contained only the natural seawater assemblage as a food source. In the first 10 experiments (see Table 1) additional carboy pairs were further enriched with the previously prepared concentrated zooplankton/phytoplankton assemblage. This was done by mixing gently the enriched assemblage while decanting beakerfuls alternately and equally into each pair of carboys. The 3 or 4 pairs in a typical experiment were thus enriched to contain progressivley increasing food concentrations (Table 1). The krill were then added. Numbers of krill per carboy were adjusted in relation to their size and the duration of the experiment (Table 1), with the aim of achieving a particle depletion of 30 to $40 \%$ during the experiment (Gifford 1993).

After mixing at the start of the experiment, initial 11 samples for chl a analysis and $400 \mathrm{ml}$ samples for $1 \%$ Lugol's preservation were siphoned from each carboy. The 1 l samples were size fractionated under gentle vacuum through $200 \mu \mathrm{m}$ and $20 \mu \mathrm{m}$ nylon mesh, $5 \mu \mathrm{m}$ polycarbonate filters and GFF filters. These were then placed in $10 \mathrm{ml}$ of $90 \%$ aqueous acetone to extract for
$>12 \mathrm{~h}$ and analysed on a Turner 112 fluorometer (see Parsons et al. 1984). A fluorometer malfunction meant that filters from the last 3 experiments were frozen $\left(-60^{\circ} \mathrm{C}\right)$ and analysed in the UK. In the last 3 experiments, 2 of the 4 control carboys were treated as initial samples, so after initial subsampling for Lugol's preservation and chl a analysis, the entire carboy contents were filtered onto a submerged $100 \mu \mathrm{m}$ sieve and preserved in $4 \%$ formaldehyde. Also at the start of each experiment, a subsample of the concentrated food medium was examined immediately under a binocular microscope to check the condition of the prey assemblage. In these experiments, $95 \%$ of individuals observed appeared to be healthy and undamaged.

The experiments were run in dim light and were stirred every 1 to $2 \mathrm{~h}$ with a plastic plunger. Published sinking rates of diatoms are of the order of a few centimeters per hour (Gifford 1993) so settling of diatoms in our $55 \mathrm{~cm}$ deep containers under regular agitation would have been only slight.

At the end of the experiments, samples for chl a analysis and Lugol's preservation were obtained from the mixed carboys in the same way as for the initial treatments. The entire contents of each carboy were then emptied onto a submerged $100 \mu \mathrm{m}$ sieve. The experimental krill were rinsed briefly and frozen at $-60^{\circ} \mathrm{C}$ for dry mass determination in the UK. The remaining sieve contents were then preserved in $4 \%$ formaldehyde in filtered seawater.

Laboratory analysis. In the UK the formaldehyde preserved food samples were analysed under a binocular microscope and all metazoan taxa were counted. A major aim was to measure the size spectrum of copepods which juvenile krill could eat, so copepods were grouped according to prosome length (Table 2). Oncaea spp., Oithona spp. and calanoid copepods have different swimming behaviour so to compare their susceptibilities to predation, these major groups were enumerated separately. Our initial aim of finer taxonomic comparisons, for example between various calanoid species, was thwarted by their abundance often being too low for statistical analysis. This forced us into simply pooling all calanoids into broad size bands. In some of the enriched incubations a Folsom plankton splitter was used to obtain countable aliquots of the more numerous taxa.

Dry masses of late copepodites of the larger species, Rhincalanus gigas, Calanoides acutus and Calanus simillimus, are available for the South Georgia region during summer (Ward \& Shreeve 1995, Atkinson et al. 1996a, b. Ward et al. 1996). This enabled the carbon contents of the larger size fractions to be estimated directly, based on the relative abundance of the copepodite stages and assuming that body carbon is $45 \%$ of dry mass (Schnack 1985). For the smaller calanoids, 
Table 2. Food taxa counted from formaldehyde samples (i.e. metazoans) and from Lugol's samples (i.e. microplankton). Size groupings of copepods were based on prosome lengths to ease rapid measuring, but their modn length (third column] is expressed as total length. Abundances of microplankton (i.e. italicised values) are expresssed as nos. $\mathrm{ml}^{-1} \mathrm{rather}^{\mathrm{k}} \mathrm{han}_{\mathrm{n}}$ nos. $\mathrm{m}^{-3}$ See 'Methods: Laboratory analysis' for carbon determinations

\begin{tabular}{|c|c|c|c|c|c|c|c|}
\hline \multirow[t]{2}{*}{ Food taxon } & \multirow[t]{2}{*}{$\begin{array}{l}\text { Length group } \\
\text { (main species) }\end{array}$} & \multirow{2}{*}{$\begin{array}{l}\text { Mean } \\
\text { length, } \\
\text { Hm (SD) }\end{array}$} & \multirow{2}{*}{$\begin{array}{l}\text { Mean } \\
\text { carbon } \\
\text { ind }^{-1} \\
\mu \mathrm{g}(\mathrm{SD})\end{array}$} & \multicolumn{2}{|c|}{$\begin{array}{l}\text { Ambient food } \\
\text { supply: control }\end{array}$} & \multicolumn{2}{|c|}{$\begin{array}{l}\text { Enriched food } \\
\text { supply: control }\end{array}$} \\
\hline & & & & $\begin{array}{l}\text { Mean no. } \\
\text { counted }\end{array}$ & $\begin{array}{l}\text { Mean } \\
\text { no. } m^{-3}\end{array}$ & $\begin{array}{l}\text { Mean no. } \\
\text { counted }\end{array}$ & $\begin{array}{l}\text { Mean } \\
\text { no. } \mathrm{m}^{-3}\end{array}$ \\
\hline \multicolumn{8}{|c|}{ Formaldehyde samples } \\
\hline Pteropoda & Limacina spp. & $\begin{array}{l}229 \\
(39)\end{array}$ & $\begin{array}{c}0.52 \\
(0.23)\end{array}$ & 139 & 2148 & 107 & 3239 \\
\hline $\begin{array}{l}\text { Copepoda: } \\
\text { nauplii }\end{array}$ & All species and sizes & $\begin{array}{l}281 \\
(54)\end{array}$ & $\begin{array}{l}0.62 \\
(0.25)\end{array}$ & 129 & 1610 & 254 & 22238 \\
\hline Oncaea spp. & All species and sizes & $\begin{array}{c}450 \\
(780)\end{array}$ & $\begin{array}{c}1.4 \\
(0.39)\end{array}$ & 4 & 92 & 28 & 2945 \\
\hline \multirow[t]{3}{*}{ Oithona spp. } & $\begin{array}{l}<350 \mu \mathrm{m} \\
(O . \text { similis })\end{array}$ & $\begin{array}{l}418 \\
(15)\end{array}$ & $\begin{array}{c}0.59 \\
(0.032)\end{array}$ & 31 & 351 & 67 & 5818 \\
\hline & $\begin{array}{l}350-750 \mu m \\
(O . \text { similis })\end{array}$ & $\begin{array}{l}660 \\
(35)\end{array}$ & $\begin{array}{l}1.3 \\
(0.11)\end{array}$ & 72 & 254 & 101 & 8267 \\
\hline & $\begin{array}{l}>750 \mu \mathrm{m} \\
(O . \text { similis })\end{array}$ & $\begin{array}{r}1069 \\
(53)\end{array}$ & $\begin{array}{c}2.0 \\
(0.22)\end{array}$ & 8 & 91 & 124 & 9932 \\
\hline \multirow[t]{4}{*}{$\begin{array}{l}\text { Small } \\
\text { Calanoida }\end{array}$} & $\begin{array}{l}<350 \mu \mathrm{m} \\
\text { (Ctenocalanus spp.. Drepanopus forcipatus) }\end{array}$ & $\begin{array}{l}441 \\
(17)\end{array}$ & $\begin{array}{c}0.77 \\
(0.025)\end{array}$ & 6 & 13 & 20 & 973 \\
\hline & $\begin{array}{l}350-750 \mu \mathrm{m} \\
\text { (D. forcipatus, Ctenocalanus spp.) }\end{array}$ & $\begin{array}{l}768 \\
(75)\end{array}$ & $\begin{array}{l}2.8 \\
(0.67)\end{array}$ & 7 & 73 & 37 & 1098 \\
\hline & $\begin{array}{l}750-1250 \mu \mathrm{m} \\
\text { (D. forcipatus, Ctenocalanus spp., } \\
\text { Metridia spp.) }\end{array}$ & $\begin{array}{l}1400 \\
(128)\end{array}$ & $\begin{array}{c}12 \\
(2.6)\end{array}$ & 13 & 159 & 41 & 911 \\
\hline & $\begin{array}{l}1250-3000 \mu \mathrm{m} \\
\text { (D. forcipatus CVI, Calanus simillimus CIV-CVI, } \\
\text { Calanoides acutus CIII, CIV) }\end{array}$ & $\begin{array}{l}2808 \\
(468)\end{array}$ & $\begin{array}{c}80 \\
(36)\end{array}$ & 2 & 26 & 19 & 324 \\
\hline $\begin{array}{l}\text { Large } \\
\text { Calanoida }\end{array}$ & $\begin{array}{l}3000-5000 \mu \mathrm{m} \\
\text { (C. acutus CV, CVI, Rhincalanus gigas CIV) }\end{array}$ & $\begin{array}{l}4657 \\
(186)\end{array}$ & $\begin{array}{l}309 \\
(29)\end{array}$ & 0.29 & 1.1 & 23 & 322 \\
\hline $\begin{array}{l}\text { Very large } \\
\text { Calanoida }\end{array}$ & $\begin{array}{l}>5000 \mu \mathrm{m} \\
(R . \text { gigas CV, CVI })\end{array}$ & $\begin{array}{l}7249 \\
(322)\end{array}$ & $\begin{array}{l}1296 \\
(469)\end{array}$ & 0.11 & 0 & 17 & 304 \\
\hline \multicolumn{8}{|c|}{ Lugol's samples } \\
\hline $\begin{array}{l}\text { Large dino- } \\
\text { flagellates } \\
\text { and ciliates }\end{array}$ & $\begin{array}{l}>40 \mu \mathrm{m} \\
\text { (Gyrodinium spp.) }\end{array}$ & $\begin{array}{c}62 \\
(20)\end{array}$ & $\begin{array}{c}0.0098 \\
(0.0085)\end{array}$ & 274 & 6.0 & 500 & 3.3 \\
\hline $\begin{array}{l}\text { Small dino- } \\
\text { flagellates } \\
\text { and ciliates }\end{array}$ & $\begin{array}{l}20-40 \mu \mathrm{m} \\
\text { (Athecate dinoflagellates) }\end{array}$ & $\begin{array}{l}26 \\
(5)\end{array}$ & $\begin{array}{c}0.00094 \\
(0.00095)\end{array}$ & 263 & 7.8 & 541 & 10 \\
\hline $\begin{array}{l}\text { Large centric } \\
\text { diatoms }\end{array}$ & $\begin{array}{l}>20 \mu \mathrm{m} \\
\text { (Thalassiosira spp.) }\end{array}$ & $\begin{array}{c}41 \\
(12)\end{array}$ & $\begin{array}{c}\text { Not } \\
\text { estimated }\end{array}$ & 56 & 1.1 & 133 & 1.6 \\
\hline $\begin{array}{l}\text { Large pennate } \\
\text { diatoms }\end{array}$ & $\begin{array}{l}>100 \mu \mathrm{m} \\
\text { (Corethron sp.) }\end{array}$ & $\begin{array}{c}279 \\
(121)\end{array}$ & $\begin{array}{l}\text { Not } \\
\text { estimated }\end{array}$ & 420 & 4.8 & 1225 & 9.2 \\
\hline
\end{tabular}

prosome length distributions were obtained by measuring 20 to 50 individuals within each of the size categories for each experiment. Dry mass to prosome length regressions were then constructed from our unpublished South Georgia summer data to estimate dry mass and hence carbon content of each size group. For Oithona spp. we used carbon to prosome length regressions from Fransz \& Gonzalez (1995). For nauplii the equations of Fransz \& Gonzalez (1995) were used, following substitution of total length for prosome length (Fransz \& Gonzalez 1997). Pteropod carbon content was estimated from the volumetric conversion of Mullin (1969), having estimated volume from linear dimensions

Microplankton were enumerated by the Utermöhl (1958) technique, settling between two and four $50 \mathrm{ml}$ 
aliquots per initial and final carboy and counting them under an inverted microscope under $\times 100$ or $\times 200$ magnification. Because this is so time consuming we limited microplankton analysis to Expts 6, 9,12 and 13, and only selected large taxa were analysed (Table 2). The sizes of 20 to 50 individuals of each food category in each experiment were measured, and the volumes of dinoflagellates and ciliates were calculated by approximation to simple shapes. Dinoflagellate carbon content was estimated by the equation in Eppley et al. (1970). Ciliate carbon was estimated as $0.19 \mathrm{pg} \mu \mathrm{m}^{-3}$ (Putt \& Stoecker 1989). Phytoplankton carbon was estimated using a carbon: chl a ratio of 50 .

Dry masses of the experimental krill were obtained by briefly rinsing the thawing material in distilled water, drying at $50^{\circ} \mathrm{C}$ for $48 \mathrm{~h}$, desiccating for $6 \mathrm{~h}$ and then weighing immediately on a Sartorius ${ }^{(1)}$ microbalance.

Gut fluorescence measurements. Krill gut fluorescence and gut evacuation rate were measured to obtain independent, 'in situ' estimates of their algal carbon ration. Four gut evacuation experiments were run, and these involved rapidly transferring -200 healthy krill from either the neuston net or the Bongo net to two $30 \mathrm{l}$ buckets of filtered seawater. Batches of $\sim 30$ krill were then removed by dip net at about $15 \mathrm{~min}$ intervals for the next 2 to $3 \mathrm{~h}$ and frozen at $-60^{\circ} \mathrm{C}$. The initial $\left(t_{0}\right)$ sample from each of these experiments was obtained by freezing $\sim 30 \mathrm{krill}$ as soon as the net came aboard. Likewise, $t_{0}$ samples were obtained from 7 other net hauls at various times of day and night (see 'Results') in order to estimate in situ gut pigment contents.

Gut evacuation experiments which involve transferring grazers to filtered seawater have been criticised because gut throughput in the absence of feeding may be longer than that during normal feeding (e.g. Penry \& Frost 1990, Pakhomov \& Perissinotto 1996). In one experiment we therefore substituted one of the $30 \mathrm{l}$ buckets of filtered seawater for filtered seawater plus starved zooplankton. This was aimed at providing krill with a food source which did not contain chlorophyll and which allowed them to continue feeding. The starved zooplankton were obtained from a $200 \mu \mathrm{m}$ net whose cod end contents were diluted to $20 \mathrm{l}$. Zooplankton (mainly copepods) were then transferred from this to $20 \mathrm{l}$ of filtered seawater with a $750 \mu \mathrm{m}$ net to exclude phytoplankton. This process was repeated about $24 \mathrm{~h}$ later, transferring zooplankton to the $30 \mathrm{l}$ bucket of filtered seawater, which was allowed to stand for 1 to $2 \mathrm{~d}$ prior to the experiments.

In the UK the frozen krill were analysed for gut pigments within 9 mo of collection. For each time point, whether for a $t_{0}$ sample or part of a gut evacuation series, -30 juvenile krill were analysed, usually in batches of 10 individuals. The krill were processed in a darkened lab by rinsing quickly in filtered seawater as they were beginning to thaw, blotting dry and placing them in homogenisation tubes with $26 \mathrm{ml}$ of $90 \%$ aqueous acetone. After homogenisation and extraction $14^{\circ} \mathrm{C}$ for $>18 \mathrm{~h}$ ) the contents were remixed and decanted into centrifuge tubes, for spinning at $3500 \mathrm{rpm}$ for 25 min. The supernatant was then analysed for chl a and phaeopigments on a scanning spectrofluorometer as described previously. Pigment contents were generally $>95 \%$ phaeopigment.

Feeding rate calculations. Clearance rates on individual cell taxa and on size fractions of chl a were calculated from Frost's (1972) equation modified to:

$$
F=\ln \left(C_{c} / C_{k}\right) \cdot V /\left(m_{k} t\right)
$$

where $F$ is the clearance rate $\left(\mathrm{ml} \mathrm{mg}^{-1}\right.$ krill dry mass $\left.\mathrm{h}^{-1}\right), C_{\mathrm{c}}$ is the final concentration in the control, $C_{\mathrm{k}}$ is the final concentration in the carboy grazed by krill, $V$ is the experimental volume in $\mathrm{ml}, m_{\mathrm{k}}$ is the krill dry mass (mg), and $t$ is the experimental duration (h). More than 2 trophic levels were present in these mixed assemblage incubations, thus leading to possible food chain effects. These were not allowed for in our clearance rate calculations, for the reasons given in 'Results: Problems of mixed assemblage incubations'.

Ingestion rates of individual food categories were calculated as the product of the clearance rate of the category ( $\mathrm{ml} \mathrm{mg}^{-1}$ krill carbon $\mathrm{h}^{-1}$ ) and its carbon concentration in the final control (mg carbon $\mathrm{ml}^{-1}$ ). Krill carbon was estimated as $40 \%$ of dry mass (Schnack 1985, Ikeda \& Kirkwood 1989). Ingestion rates were then expressed as a daily carbon ration with the assumption that krill feeding rates recorded during each incubation reflect the daily average rate.

\section{RESULTS}

\section{Problems of mixed assemblage incubations}

A problem with such mixed assemblage incubations is that feeding and particle depletion may occur in the controls, for instance due to copepods feeding on phytoplankton or protozoans. Furthermore, this depletion will not be the same as that in the krill carboys where some of these copepods are removed by the krill. This could lead to an underestimation of krill feeding rate on the smaller taxa, which are eaten both by zooplankton and krill. Two factors, however, suggest that this problem was slight.

First, chl $a$ in the control carboys did not decrease significantly during the experiments (t-test, $\mathrm{p}>0.05$ ). Indeed the median ratio of total chl a in initial to final controls was 0.998 (interquartile range 0.946 to 1.06 ). 
Likewise, $t$-tests failed to reveal significant changes in metazoan numbers within the controls. However, abundance of large dinoflagellates and ciliates decreased by $\sim 10 \%$, with the median ratio in initial to final controls being 1.10 (interquartile range 0.91 to 1.28). Against these slight changes in the controls, the effect of krill grazing was to remove a median of $26 \%$

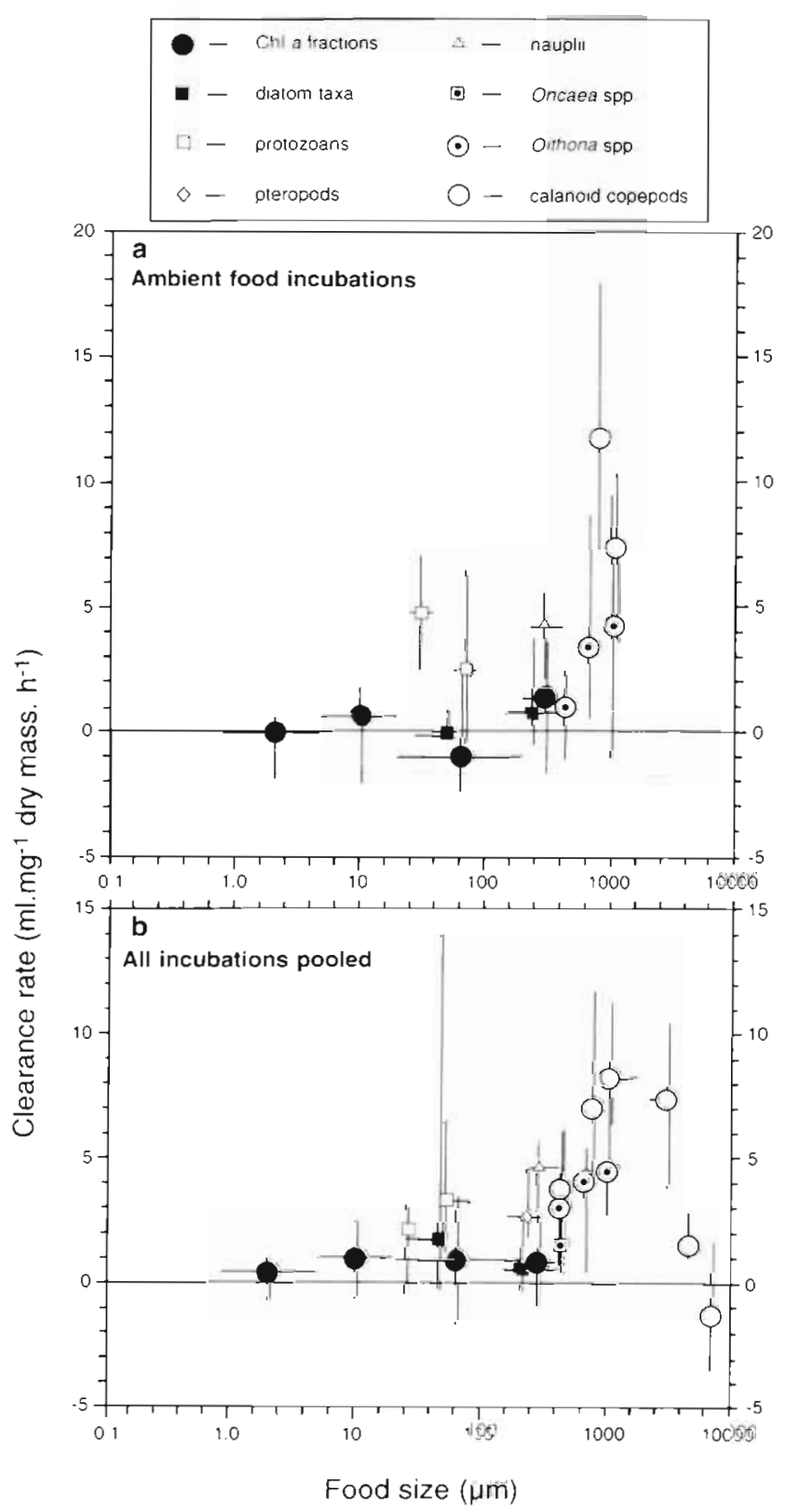

Fig. 1. Euphausia superba. Mass specific feeding rate on the various prey categories, versus their length. (a) Median and interquartile range in clearance rates for $21 \mathrm{krill}$ incubations in natural seawater; (b) these results for all 43 incubations (ambient plus enriched). Horizontal bars: range in size of the food items, across the experiments. Only those incubations where $>20$ individuals were counted in the final control are included in this figure. Food items are described in Table 2 of metazoans over all experiments (interquartile range 14 to $39 \%$ ). Given the rather small changes within the controls described above, removal of only one-quarter of the metazoans would probably do little to release microplankton or the smaller metazoans from grazing pressure by copepods.

The second indication that our calculated feeding rates on microplankton and small metazoans are not artificially low comes from the ambient seawater incubations. In these, krill biomass was usually 1 to 2 orders of magnitude higher than that of other metazoan grazers (Table 1). Given the low numbers of metazoans in the natural seawater, it is likely that the large majority of grazing in these incubations would have come from krill. These ambient incubations suggested, like the enriched ones, that clearance rates on microplankton were low (see 'Results: Food selectivity'). Because the mass specific clearance rates of krill are similar to published values for the biomass dominant Antarctic copepods (e.g. Schnack 1985, Schnack-Schiel et al. 1991, Atkinson et al. 1996a) most of the grazing, even in the enriched incubations, probably came from krill.

\section{Food selectivity}

Exploratory analysis was aimed at determining differences in clearance rate between experiments which differed in location, food supply, duration and size of krill. Although some differences were observed, the main relationship was between food size and clearance rate (Fig. 1). This relationship appeared to be similar for both the ambient and the enriched experiments, so in the absence of observable differences the whole data set was pooled.

Fig. 1 shows that clearance rates on phytoplankton were low, and that highest rates were on larger particles. Large ciliates and dinoflagellates (comprising mainly the heterotrophic dinoflagellate Gyrodinium spp., so hereafter simply termed (protozoans') were cleared faster generally than phytoplankton of similar length. Likewise, nauplii were often cleared faster than pteropods, and calanoid copepods tended to be cleared faster than cyclopoids of similar length. Given the wide variability among experimental conditions and the counting imprecision, we compared clearance rates on all 3 cyclopoid length classes against those on calanoids which were in the same range of body length (i.e. the $<350$ and 350 to $750 \mu \mathrm{m}$ categories). For all data within these size categories a Mann-Whitney test indicated significantly higher clearance rates on calanoids $(p<0.05)$.

Krill length ranged from about 25 to $40 \mathrm{~mm}$ among experiments but no differences were discernible in the particle size spectrum ingested. Any such difference, however, may have been obscured by our coarse size 
groups of food. Declining clearance rates were observed on the 2 largest size fractions, and a Mann-Whitney test revealed that clearance rates on the largest copepod group (CV and CVI of Rhincalanus gigas) were not significantly different from zero $(p>0.05)$.

\section{Diet in relation to food availability}

The estimated contributions of phytoplankton, protozoans and various copepod groups to the available carbon in the food source varied, both among experiments and in relation to the degree of food enrichment. However prior analysis revealed a common trend. All incubations were grouped into 3 concentrations of available food (Fig. 2). These were ambient (natural unmodified seawater, usually $<100 \mathrm{mg} \mathrm{C} \mathrm{m}^{-3}$ ), moderately enriched food $(<300 \mathrm{mg} \mathrm{C}$ $\left.\mathrm{m}^{-3}\right)$ and highly enriched food $(>300$ $\mathrm{mg} \mathrm{C} \mathrm{m} \mathrm{m}^{-3}$ ).

The carbon in the ambient food was mainly as small cells (phytoplankton and protozoans) but krill diet was dominated by small calanoids, protozoans and chl a $>5 \mu \mathrm{m}$. Because the carbon ingested is the product of the clearance rate and the available carbon concentration, krill's rapid ingestion of calanoids and protozoans relative to phytoplankton reflects the higher clearance rates on these taxa (Fig. 1)

For the enriched food supply the larger metazoan categories feature even more prominently in the diet. However, large diatoms were still an important fraction of the ration. At the highest enrichment, the 2 largest copepod categories dominated the carbon in the food supply, but the low or zero clearance rates on them made them smaller components of the diet.

The range bars in Fig. 2 are large, which reflects both the range of food among experiments (Table 2) and the imprecision in counting rarer food items. The general pattern described above, however, is reflected in the results from the individual experiments (e.g. Fig. 3). With the exception of the largest category of copepods, the diet contains a higher incidence of large food items than in the available food.

\section{Functional response}

Fig. 4 shows the total carbon ration and the clearance rate of total metazoans versus concentration of available food (i.e. all food categories in Figs. 1 \& 2 except for Rhincalanus gigas CV and CVI). For the data set as a whole, the ration is positively related to food concentration over the range of concentrations offered $(p<0.05)$. Lines link the data points for individual experiments, and these show a more varied picture. In several experiments there appears to be a roughly linear increase in ration with available carbon

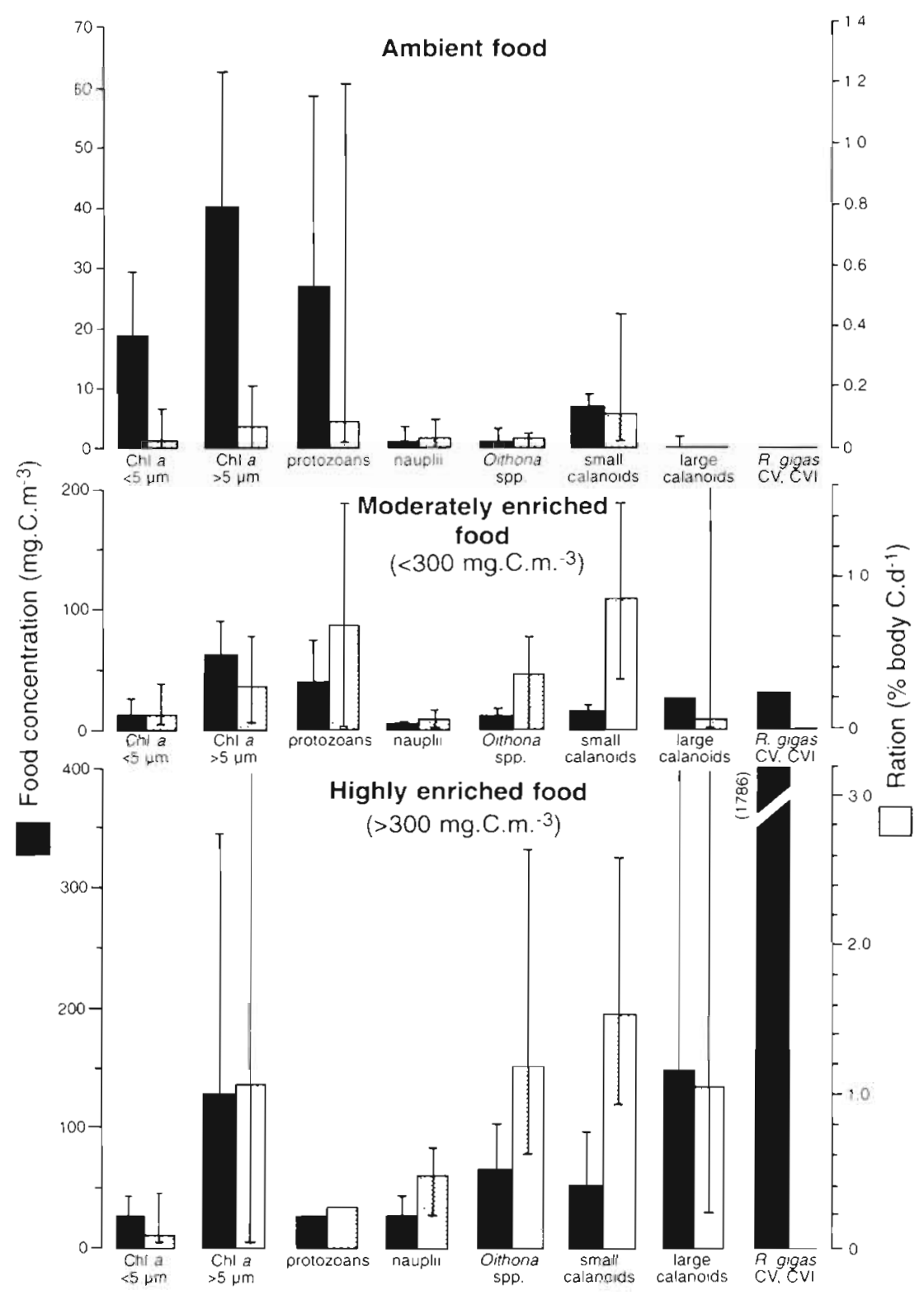

Fig. 2. Euphausia superba. Comparison of median values of available carbon (solid bars, left axis) and the contribution to krill carbon ration (stippled bars, right axis) of major dietary items across all 13 experiments. Interquartile ranges are denoted on the bars 
over all food concentrations. In others, however, the slope decreases at food concentrations above about $200 \mathrm{mg} \mathrm{C} \mathrm{m} \mathrm{m}^{-3}$. However there is no clear indication from the data set as a whole that food saturation had been reached. A caution in the interpretation of these functional responses is that several of the incubations lasted only one quarter of a day (Table 1) but the rations were computed assuming that the measured ingestion rates were sustained for a whole day. Pond et al. (1995) suggested that in some circumstances the daily ration of krill might be limited by their speed of digesting the food, rather than of ingesting it. If this is so, then short incubations in abundant food could lead to overestimates of daily rations. There was no pattern, however, in the shape of the functional responses among the experimental conditions: carbon rations $>10 \%$ were found for both large and small krill and

\section{Food source}

Ambient

(130 $\mathrm{mgC} \mathrm{m}^{-3}$ )

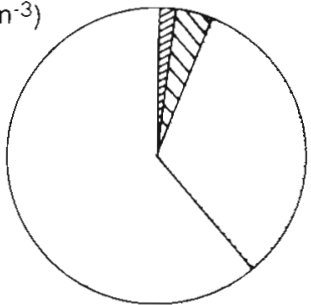

Enriched

(340 $\mathrm{mgC} \mathrm{m}^{-3}$ )

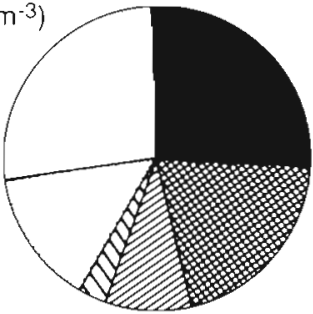

Enriched $\left(842 \mathrm{mgC} \mathrm{m}^{-3}\right)$
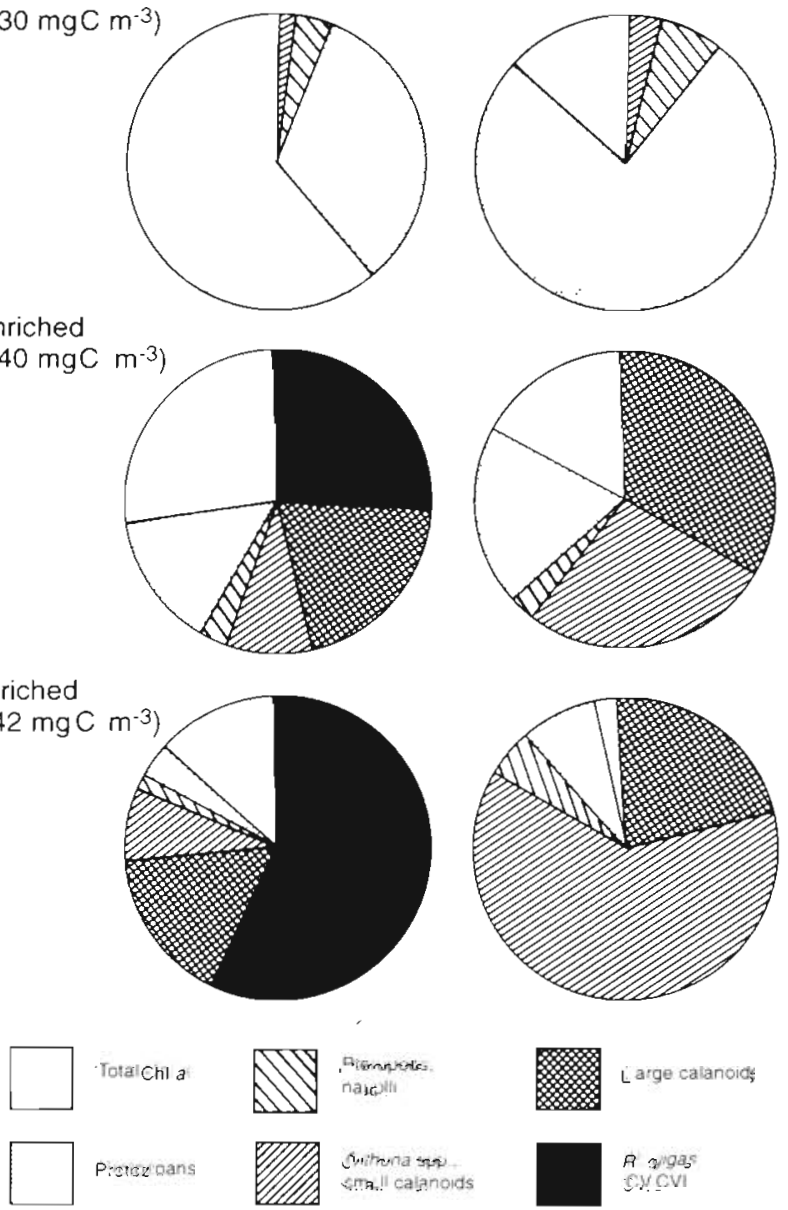

Large calanoids
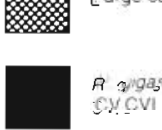

Fig. 3. Euphausia superba. Example of the contribution of various sized taxa to the food source and krill diet in Expt 6. Progressively denser hatching denotes larger food items; see Table 2 for their definition

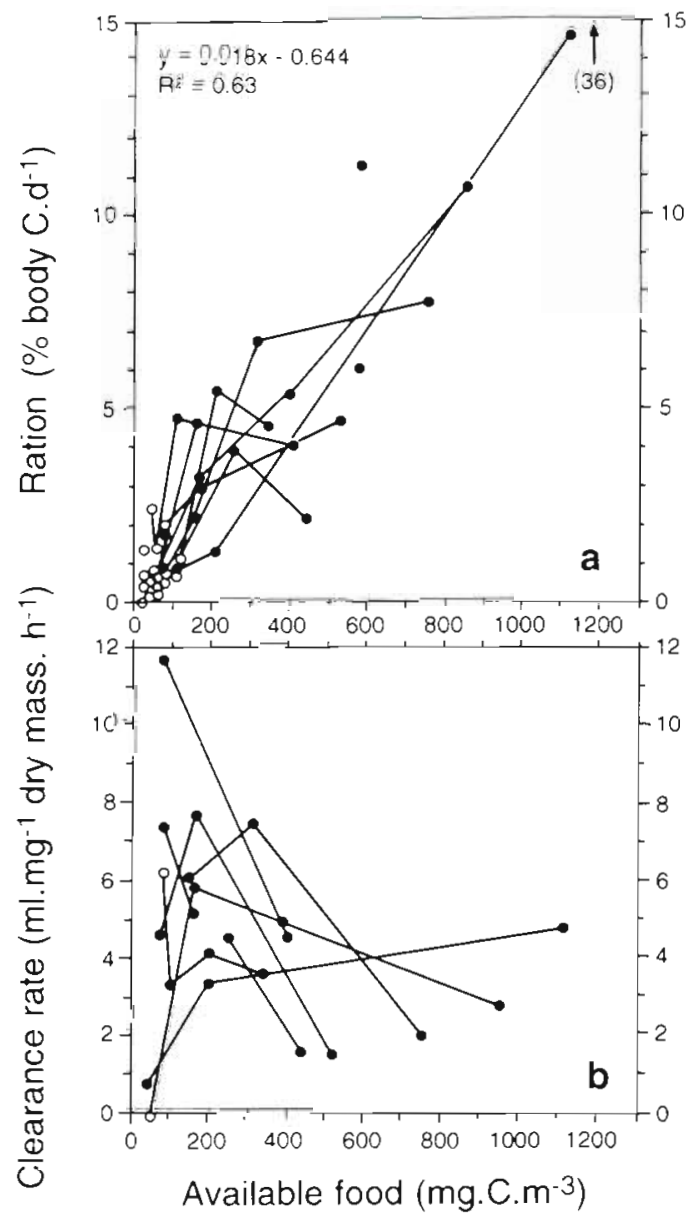

Fig. 4. Euphausia superba. (a) Daily ration and (b) clearance rate versus concentration of ingestable food. Each point represents the result from a krill/control pair (o) Ambient seawater; enriched food incubations. The regression in (a) represents all data pooled. For (b) the regression was not significant, and only data from the experiments testing enrichment have been plotted. Lines link results for the various experiments

were calculated over both long $(\sim 1 \mathrm{~d})$ and short $(6 \mathrm{~h})$ incubations.

The picture for clearance rate versus food concentration (Fig. 4b) is inconclusive. For all the data which are plotted there is no significant correlation, although for the individual experiments clearance rates at concentrations > $200 \mathrm{mg} \mathrm{C} \mathrm{m}^{-3}$ were often lower than those at 100 to $200 \mathrm{mg} \mathrm{C} \mathrm{m}^{-3}$

\section{Gut fluorescence estimates of algal ingestion}

The gut fluorescence results were obtained mainly from shelf and oceanic monitoring sites near South Georgia (Table 3). Initial pigment values were low, with a mean of $1.1 \mathrm{ng}$ pigment $\mathrm{mg}^{-1}$ krill dry mass 
Table 3. Gut fluorescence results, summarising initial $\left(t_{0}\right)$ pigment values and gut evacuation rate constants, $k$. Dashes mean that $k$ was not determined

\begin{tabular}{|c|c|c|c|c|c|c|}
\hline $\begin{array}{l}\text { Date } \\
\text { (1996) }\end{array}$ & Location & $\begin{array}{l}\text { Local time } \\
\text { (GMT }-3 \mathrm{~h})\end{array}$ & $\begin{array}{c}\text { Mean } t_{0} \\
\text { (ng pigment } \\
\mathrm{mg}^{-1} \text { krill dry mass) }\end{array}$ & $\begin{array}{c}\text { No. krill } \\
\text { analysed for } \\
t_{0} \text { value }\end{array}$ & $\begin{array}{c}k \\
\left(\mathrm{~h}^{-1}\right)\end{array}$ & $\begin{array}{c}\mathrm{R}^{2} \text { for } \\
\text { determination } \\
\text { of } k\end{array}$ \\
\hline 12 Jan & $\begin{array}{l}53^{\circ} 53^{\prime} \mathrm{S}, 38^{\circ} 48^{\prime} W \text { (site on NW } \\
\text { shelf of South Georgia) }\end{array}$ & $23: 50$ & 1.2 & 56 & 0.17 & 0.45 \\
\hline $24 \mathrm{Jan}$ & As above & $01: 20$ & 1.0 & 35 & - & - \\
\hline $24 \mathrm{Jan}$ & As above & $01: 30$ & 1.7 & 63 & - & - \\
\hline $24 \mathrm{Jan}$ & As above & $05: 40$ & 1.5 & 30 & - & - \\
\hline $24 \mathrm{Jan}$ & As above & $10: 00$ & 1.4 & 18 & - & - \\
\hline $27 \mathrm{Jan}$ & $\begin{array}{l}53^{\circ} 02^{\prime} \mathrm{S}, 39^{\circ} 27^{\prime} \mathrm{W} \text { (oceanic site NW } \\
\text { of South Georgia) }\end{array}$ & $00: 50$ & 0.8 & 22 & - & - \\
\hline $29 \mathrm{Jan}$ & As above & $00: 25$ & 1.8 & 22 & 0.27 & 0.51 \\
\hline $29 \mathrm{Jan}$ & As above & $09: 15$ & 1.2 & 43 & - & - \\
\hline $30 \mathrm{Jan}$ & $\begin{array}{l}53^{\circ} 38^{\prime} \mathrm{S}, 41^{\circ} 17^{\prime} \mathrm{W} \text { (near Shag Rocks, } \\
\mathrm{W} \text { of South Georgia) }\end{array}$ & $02: 32$ & 0.47 & 30 & - & - \\
\hline $14 \mathrm{Feb}$ & $\begin{array}{l}49^{\circ} 39^{\prime} \mathrm{S}, 40^{\circ} 17^{\prime} \mathrm{W} \text { (vicinity of Polar } \\
\text { Front, north of South Georgia) }\end{array}$ & $01: 15$ & 0.54 & 37 & 0.22 & 0.18 \\
\hline $22 \mathrm{Feb}$ & $\begin{array}{l}53^{\circ} 54^{\prime} \mathrm{S}, 38^{\circ} 39^{\prime} \mathrm{W} \text { (the site on } \\
\text { NW shelf of South Georgia) }\end{array}$ & $00: 21$ & 0.55 & 38 & 0.16 & 0.23 \\
\hline
\end{tabular}

based on 11 values during the cruise. This equates to 69 ng pigment ind.$^{-1}$. Most of the $t_{0}$ pigment determinations were made in the early hours of the morning when krill were readily caught from the foredeck neuston net, but 3 tuvalues were obtained during daylight, and these values are within the range of nighttime values. Although some studies have found krill feeding mostly at night (e.g. Drits \& Semenova 1989), a larger number, including other summertime South Georgia studies (e.g. Morris et al. 1983, Pakhomov et al. 1997), show krill feeding during both day and night with no obvious diel pattern.

The gut evacuation data were plotted for each experiment on a log-linear scale. Inspection of these suggested that in one of the experiments (shown in Fig. 5) the slope of the exponential decay might have slowed after the first hour. This was not apparent in the other 3 experiments so for consistency negative exponential models were fitted over their entire 2 to $3 \mathrm{~h}$ durations. The gut evacuation rate constants in filtered seawater and in the presence of starved zooplankton were not significantly different (analysis of variance of slopes, $p<0.05)$. All data for this experiment were therefore pooled to calculate the gut evacuation rate constant. Across all 4 experiments, gut evacuation rate constants ranged from 0.16 to $0.27 \mathrm{~h}^{-1}$. Corresponding reciprocals, or gut passage times, ranged from 3.7 to $6.3 \mathrm{~h}$ which is within the range of values most frequently obtained for krill (see Perissinotto \& Pakhomov 1996).

Pigment degradation was not measured, although in a summertime South Georgia study, Perissinotto \&
Pakhomov (1996) found that, on average, $84 \%$ of ingested pigment was converted to non-fluorescent compounds. From our results, algal carbon ingestion was therefore estimated from the diel mean gut pigment content, adjusted for $84 \%$ pigment loss (i.e. $6.9 \mathrm{ng}$ pigment mg $^{-1}$ krill dry mass) and the mean gut evacuation rate constant $\left(0.21 \mathrm{~h}^{-1}\right)$. Integrating over $24 \mathrm{~h}$ and using the same carbon conversion factors as previously ('Methods') yields an algal carbon ration of $0.43 \%$ body $\mathrm{C} \mathrm{d}^{-1}$. However, if more than three-quarters of the pigment were indeed undetectable, the calculated

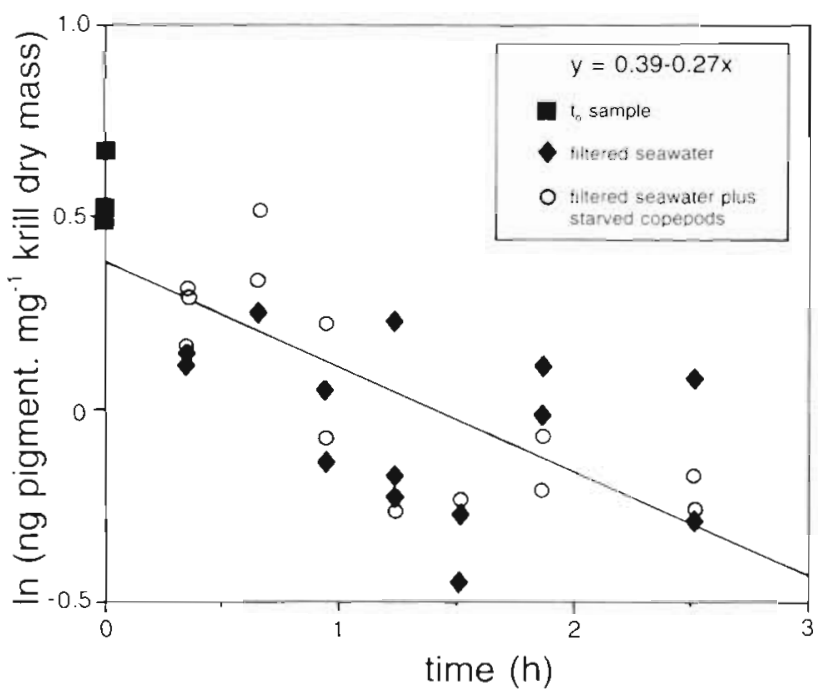

Fig. 5. Euphausia superba. Time course of gut evacuation in filtered seawater and in filtered seawater plus starved copepods 
algal carbon ration would be very sensitive to the exact degree of pigment destruction. Despite this uncertainty, the low value we have estimated is in line with the algal rations from the incubations at moderately enriched food (Fig. 2).

\section{DISCUSSION}

\section{Feeding behaviour}

There is nothing new in the observation that krill eat zooplankton as well as phytoplankton (e.g. Boyd et al. 1984, Ikeda 1984, Price et al. 1988, Hopkins \& Torres 1989, Granéli et al. 1993, Hopkins et al. 1993). Indeed, zooplankton fragments comprised, on average, onefifth of identifiable items in the guts of South Georgia krill during the summer of 1994 (Pakhomov et al. 1997). This study aimed to quantify the sizes and taxa of zooplankton that are eaten most readily, and to compare them to protozoans and phytoplankton in the ration of South Georgia krill. In similar experiments, Price et al. (1988) offered CVI Metridia gerlachei, CIV Euchaeta antarctica and a cultured diatom in various concentrations to adult krill. They found that in mixtures of copepods and phytoplankton, copepods were cleared faster. Our data show likewise, although our mass specific clearance rates on 1 to $3 \mathrm{~mm}$ copepods are roughly 2 to 3 times their values on larger copepods. This could reflect the higher metabolic rates of our smaller krill, the slightly higher temperatures, or possibly that the copepods in their experiments were of suboptimal size for ingestion.

How applicable are these incubations to predatorprey interactions in the sea? Turbulence is now recognised as important in governing the strategies of detection and avoidance between predator and prey, and thus in dictating feeding behaviour (Saiz \& Kiorboe 1995). However the range of turbulence which krill actually encounter is currently difficult either to ascertain or to recreate. Most work on turbulence has been with the copepod Acartia spp., which preys on ciliates using a 'hop and sink' ambush mode. Saiz \& Kiørboe (1995) cautioned that predators with other feeding modes may respond differently to changes in turbulence. The krill in our experiments were observed mostly moving erratically, frequently turning and with minimal interactions with the container walls. Similar turning movements, observed in situ by divers, were described by Hamner et al. (1983) to signify active feeding. In the absence of obviously unnatural behaviour, we suggest that our results give insights into the spectrum of prey which young krill can capture.

A complementary approach is gut content analysis (Barange et al. 1991, Gibbons et al. 1991, Hopkins et al.
1993). Although valuable in showing some of the food items which are eaten in situ, it under-represents soft bodied food items and maceration of food can make identification difficult (Theilacker et al. 1993, authors' pers obs.). Also it is hard to deduce either feeding rates or feeding selectivity. For example, both diatoms and Oithona spp. have been found to feature in the guts of krill (Hopkins 1985, Hopkins \& Torres 1989). In our experiments, however, these 2 taxa were the most numerous ones with hard parts, and would also have predominated in krill guts, despite the fact that they were cleared at submaximal rates and did not dominate carbon intake. A $60 \mathrm{mg}$ krill needs to eat only two $0.6 \mathrm{mg}$ copepods every other day to meet its minimum metabolic requirements. Given that krill gut passage times might vary from -40 min (Clarke et al. 1988) to -8 h (Antezana et al. 1982, Perissinotto \& Pakhomov 1996), few such copepods would be found in their guts.

The gut fluorescence results provide independent support for omnivorous feeding. Even allowing for $84 \%$ of pigment destroyed, our estimate of algal carbon ration, only $\sim 0.43 \%$ of body carbon $\mathrm{d}^{-1}$, is much less than the minimum uptake for respiration, $\sim 1.0$ to $1.5 \%$ body carbon $d^{-1}$ (Clarke \& Morris 1983, HolmHansen \& Huntley 1984, Ikeda \& Kirkwood 1989). Likewise, Pakhomov et al. (1997) found that the algal carbon ration of krill was only about one-third of that computed from faecal carbon egestion, and that zooplankton were a significant fraction of their gut contents.

Three pelagic feeding modes have been described for krill; 'pump filtering' (Kils 1983), 'compression filtering' (Dalley \& McClatchie 1989) and raptorial capture of larger particles (Price et al. 1988). With krill food ranging over 1000-fold in length, several capture mechanisms are to be expected. Switching between methods has been suggested to explain the feeding behaviour of some copepods (e.g. Price et al. 1983, Kiørboe et al. 1996). Possibly our krill were mainly feeding raptorially rather than suspension feeding, because clearance rates on motile taxa were higher than those on diatoms, even when diatoms dominated carbon.

Among the copepod prey, some size- and taxonspecific trends emerge. The cyclopoid Oithona spp. was cleared significantly more slowly than calanoids of similar length. This is surprising, because cyclopoids were more numerous, and in the enriched carboys their contribution to available carbon was similar to that of small calanoids (Table 2). The calanoids were mainly copepodites of Drepanopus forcipatus, Ctenocalanus sp. and Metridia spp., which moved almost continuously, unlike Oithona spp. which spent much time motionless. So possibly the motionless Oithona spp. were either harder for krill to detect, or better equipped to detect and avoid approaching krill. Suc- 
cessful escape responses might explain the lower clearance rates on the largest copepods such as Rhincalanus gigas, because their size and domination of carbon in the enriched incubations could have made them an ideal food source.

\section{Daily ration}

Could the ambient incubation water have sustained krill growth? Median ambient carbon concentrations were $56 \mathrm{mg} \mathrm{C} \mathrm{m}^{-3}$ and chl a median was $1.0 \mathrm{mg} \mathrm{chl} \mathrm{a}$ $\mathrm{m}^{-3}$. In ambient seawater the median krill ration was $0.68 \%$ of body carbon $\mathrm{d}^{-1}$ (range 0 to $2.6 \%$ ). This value could be revised upwards, as protozoans $<20 \mu \mathrm{m}$ were not counted, and Lugol's fixation could have caused losses and shrinkage of delicate protozoans (Stoecker et al. 1994). Also our carbon estimates for the small metazoans, based on body lengths, are subject to error. Nevertheless, most rations were well below the values of $\sim 1.0$ to $1.5 \%$ needed to fuel respiration (Clarke \& Morris 1983, Holm-Hansen \& Huntley 1984, Ikeda \& Kirkwood 1989). So the krill either had in situ clearance rates greatly exceeding our measured values, they were starving, or they were exploiting layers or patches of food. The first explanation is unlikely, as our mass specific clearance rates are at the upper end of literature values, whether from in vitro or in situ experiments or predicted from growth rates (see Quetin et al. 1994). The likely explanation is that of McClatchie (1985), Price et al. (1988) and others: that omnivorous euphausiids need to exploit patches or layers of zooplankton.

Are the food concentrations in the enriched experiments, and the rations from them, achieved within zooplankton patches? Around South Georgia very little is known of horizontal patchiness, but oblique tows with a Longhurst Hardy Plankton Recorder (LHPR) have revealed high density layers of zooplankton (Table 4). Total carbon concentrations in Table 4 were calculated on the same taxa and with the same conversion factors as in our experiments (Table 1) and suggest that on average, available carbon in these layers are 2 to 13 times higher than in the ambient incubations. Because the values in Table 4 are based on a small number of untargeted LHPR tows, fine-scale layering and patchiness would have been missed. Therefore the enriched incubations may not have overplayed the zooplankton densities actually reached in the sea.

Another facet of this food availability problem may be the indication that krill's ingestion rate did not reach a plateau, even at the high food concentrations of the enriched experiments. Price et al. (1988) showed this more conclusively, and it could suggest that concentrated zooplankton patches are exploited effectively. At high zooplankton concentrations, the estimated ration of juvenile krill exceeded $10 \%$ of body carbon per day. Apart from the ration of 17 to $24 \%$ estimated by Clarke et al. (1988), 10\% is in the upper range of literature values (see Table 6 in Pakhomov et al. 1997). Krill are enigmatic in their ability to withstand prolonged food shortage (Ikeda \& Dixon 1982). Perhaps the corollary of this is their ability to eat quickly during intermittent contacts with food patches.

\section{Impact of krill on their food supply}

A multifrequency acoustic survey, conducted in two $80 \times 100 \mathrm{~km}$ grids north of South Georgia in January 1996, gave an overall mean estimate of $33 \mathrm{~g}$ krill wet mass $\mathrm{m}^{-2}$ (Brierley et al. 1997). These krill resided mainly in the top $100 \mathrm{~m}$ (A.S. Brierley \& J. L. Watkins pers. comm.). We have estimated their potential impact

Table 4. Estimates of carbon concentration at sites in the South Georgia region, based on oblique sampling with a LHPR, and concurrent profiling of chl a. Phytoplankton carbon was determined from mean values within the surface mixed layer using a carbon: chl a ratio of 50. Zooplankton biomass values are based on the depth stratum where zooplankton biomass was highest

\begin{tabular}{|c|c|c|c|c|c|}
\hline $\begin{array}{l}\text { Station } \\
\text { position }\end{array}$ & Sampling & $\begin{array}{c}\text { Mean } \\
\text { mesozooplankton } \\
\text { biomass, } \\
\text { mg C m }^{-3} \text { (range) }\end{array}$ & $\begin{array}{c}\text { Mean } \\
\text { phytoplankton } \\
\text { biomass, } \\
\text { mg C m}{ }^{-3}\end{array}$ & $\begin{array}{c}\text { Mean biomass of } \\
\text { mesozooplankton } \\
\text { plus phytoplankton, } \\
\mathrm{mg} \mathrm{C} \mathrm{m}^{-3}\end{array}$ & Source \\
\hline $\begin{array}{l}\text { South Georgia } \\
\text { shelf }\end{array}$ & $\begin{array}{l}2 \text { LHPR profiles } \\
\text { in Jan }\end{array}$ & $78(54-101)$ & 132 & 210 & $\begin{array}{l}\text { Ward et al. } \\
\text { (1995) }\end{array}$ \\
\hline $\begin{array}{l}\text { Oceanic site NW } \\
\text { of South Georgia }\end{array}$ & $\begin{array}{l}2 \text { LHPR profiles } \\
\text { in Jan }\end{array}$ & $55(38-72)$ & 50 & 105 & $\begin{array}{l}\text { Ward et al. } \\
\text { (1995) }\end{array}$ \\
\hline $\begin{array}{l}\text { South Georgia } \\
\text { shelf }\end{array}$ & $\begin{array}{l}7 \text { LHPR profiles } \\
\text { in Jan }\end{array}$ & $119(25-170)$ & 625 & 744 & $\begin{array}{l}\text { Atkinson et al. } \\
\text { (1996a) }\end{array}$ \\
\hline $\begin{array}{l}\text { Polar Frontal } \\
\text { Zone north of } \\
\text { South Georgia }\end{array}$ & $\begin{array}{l}5 \text { LHPR profiles } \\
\text { in Feb }\end{array}$ & $79(23-215)$ & 40 & 119 & $\begin{array}{l}\text { Atkinson et al. } \\
\text { (1996b) }\end{array}$ \\
\hline
\end{tabular}


Table 5. Predation impacts from Antarctic macroplankton and mortality estimates of Antarctic copepods

\begin{tabular}{|c|c|c|c|c|}
\hline Predator & Prey & $\begin{array}{l}\text { Estimated predation } \\
\text { impact or mortality rate }\end{array}$ & Notes & Source \\
\hline $\begin{array}{l}\text { Predation impacts } \\
\text { Euphausia superba } \\
\text { juveniles }\end{array}$ & $\begin{array}{l}\text { Small calanoid } \\
\text { copepods }\end{array}$ & $\begin{array}{l}-1.6 \% \text { of top } 100 \mathrm{~m} \\
\text { cleared } \mathrm{d}^{-1}\end{array}$ & $\begin{array}{l}\text { Extrapolated from bottle } \\
\text { incubations }\end{array}$ & This study \\
\hline $\begin{array}{l}\text { Themisto } \\
\text { gaudichaudii }\end{array}$ & Mesozooplankton & $\begin{array}{l}0.56 \% \text { of standing stock } \\
\text { ingested } \mathrm{d}^{-1}\end{array}$ & $\begin{array}{l}\text { From ration of } 6.3 \% \\
\text { dry mass } d^{-1} \text { and mean } \\
\text { biomass estimates of } \\
\text { predators and prey from } \\
10 \text { South Georgia sites }\end{array}$ & $\begin{array}{l}\text { Pakhomov \& } \\
\text { Perissinotto } \\
(1996)\end{array}$ \\
\hline $\begin{array}{l}\text { Eukrohnia } \\
\text { hamata }\end{array}$ & Copepods & $\begin{array}{l}0.05 \% \text { of standing stock } \\
\text { removed } \mathrm{d}^{-1}\end{array}$ & $\begin{array}{l}\text { Winter time predation } \\
\text { impact based on gut content } \\
\text { analysis from Gerlache } \\
\text { Strait, Antarctic Peninsula }\end{array}$ & Oresland (1990) \\
\hline \multirow[t]{3}{*}{ Mortality estimates } & Calanoides acutus & $7 \%$ of population die $\mathrm{d}^{-1}$ & $\begin{array}{l}\text { Mortality estimate of } \\
\text { C. acutus population in } \\
\text { Gerlache Strait in spring }\end{array}$ & $\begin{array}{l}\text { Huntley et al. } \\
\text { (1994) }\end{array}$ \\
\hline & Calanoides acutus & $0.7 \%$ of population die $\mathrm{d}^{-1}$ & $\begin{array}{l}\text { Mortality estimate based } \\
\text { on a compilation of data } \\
\text { from the Scotia Sea }\end{array}$ & $\begin{array}{l}\text { Atkinson et al. } \\
\text { (1997) }\end{array}$ \\
\hline & Rhincalanus gigas & $0.4 \%$ of population die $\mathrm{d}^{-1}$ & $\begin{array}{l}\text { Mortality estimate based } \\
\text { on a compilation of winter } \\
\text { data from Scotia Sea }\end{array}$ & $\begin{array}{l}\text { Ward et al. } \\
\text { (1997) }\end{array}$ \\
\hline
\end{tabular}

by assuming that their dry mass was $25 \%$ of wet mass (Morris et al. 1988) and secondly that they fed in the top $100 \mathrm{~m}$. Krill clearance in this Iayer was then calculated as the product of the mean biomass density of krill ( $83 \mathrm{mg}$ dry mass $\mathrm{m}^{-3}$ ) and their clearance rates of phytoplankton, protozoans and small calanoid copepods (respectively 1, 3 and $8 \mathrm{ml} \mathrm{mg}^{-1}$ dry mass $\mathrm{h}^{-1}$; see Fig. 1). This gives krill clearing $0.2,0.6$ and $1.6 \%$ of the top $100 \mathrm{~m}$ layer daily of phytoplankton, large protozoans and copepods. Obviously these are simple average estimates, and horizontal and vertical migration, coupled with feeding variability, will dictate local grazing pressure. Nevertheless the impact of krill on primary production seems slight, given that phytoplankton doubling times are of the order of a few days (Priddle et al. 1995, 1997). In contrast, even the smaller Antarctic copepods have life cycles of $\sim 1$ yr (e.g Schnack-Schiel \& Mizdalski 1994, Metz 1996, Atkinson in press). In the absence of advection or recruitment, a daily predation of only $-1.6 \%$ of copepods would account for $\sim 40 \%$ of a population in $1 \mathrm{mo}$. Indeed, this impact is high compared to other studies of predation and mortality among Antarctic zooplankton (Table 5).

Further evidence for a direct interaction between krill and copepods comes from a study of the correlation in their abundance at 2 scales (our unpubl. data). On an interannual scale the present (1996) season was compared with the 1994 season, when krill biomass was only $\sim 14 \%$ of its present value (Brierley et al. 1997). Copepod numbers north of the island during the krill-rich season averaged only $\sim 25 \%$ of those during the poor krill year. On a small horizontal scale (10s to $100 \mathrm{~s}$ of $\mathrm{m}$ ) a series of LHPR tows during the present season showed that copepod numbers were low within krill swarms, but dispersed krill tended to be located within aggregations of copepods.

Although these results all point to an impact of krill on copepods, we are not suggesting that this lasted the whole spring or summer. Krill can feed very efficiently on phytoplankton (e.g. Antezana \& Ray 1984). An intense and widespread phytoplankton bloom developed near the end of our field work (unpubl. cruise report, British Antarctic Survey). Krill feeding on this bloom could mean less impact on copepods. The detail of such feeding interactions, however, will need to come from fine- and micro-scale studies of feeding, behaviour and distribution (e.g. Hamner et al. 1983, Price 1989).

Acknowledgements. We thank the officers, crew and scientists aboard RRS 'James Clark Ross' who assisted during the field season. Our particular thanks to D. G. Bone for designing and making the motion-compensating Bongo net and to Dr G. C. Cripps for being mellow in sharing cold room facilities. This manuscript was improved by the comments and discussion with Prof. A. Clarke and Drs A. S. Brierley, J. Priddle and P. Ward. 


\section{LITERATURE CITED}

Antezana T, Ray K (1984) Active feeding of Euphausia superba in a swarm north of Elephant Island. J Crustac Biol 4:142-155

Antezana T, Ray K, Helo C (1982) Trophic behaviour of Euphausia superba Dana in laboratory conditions. Polar Biol 1:77-82

Atkinson A (in press) Life cycle strategies of epipelagic copepods in the Southern Ocean. J Mar Syst

Atkinson A, Schnack-Schiel SB, Ward P, Marin V (1997) Regional differences in the life cycle of Calanoides acutus (Copepoda: Calanoida) within the Atlantic sector of the Southern Ocean. Mar Ecol Prog Ser 150:99-111

Atkinson A, Shreeve RS, Pakhomov EA, Priddle J, Blight SP, Ward P (1996a) Zooplankton response to a phytoplankton bloom near South Georgia, Antarctica. Mar Ecol Prog Ser $144: 195-210$

Atkinson A, Ward P, Murphy EJ (1996b) Diel perıdicity of subantarctic copepods: relationships between vertical migration, gut fullness and gut evacuation rate. J Plankton Res 18:1387-1405

Barange M, Gibbons MJ, Carola M (1991) Diet and feeding of Euphausia hanseni and Nematoscelis megalops (Euphausiacea) in the northern Benguela Current: ecological significance of vertical space partitioning. Mar Ecol Prog Ser $73: 173-181$

Boyd CM, Heyraud M, Boyd CN (1984) Feeding of the Antarctic krill, Euphausia superba. J Crustac Biol 4 (Spec No. 1):123-141

Brierley AS, Watkins JL, Murray AWA (1997) Interannual variability in krill abundance at South Georgia. Mar Ecol Prog Ser 150:87-98

Clarke A, Morris DJ (1983) Towards an energy budget for krill: the physiology and biochemistry of Euphausia superba Dana. Polar Biol 2:69-86

Clarke A, Quetin LB, Ross RM (1988) Laboratory and field estimates of faecal pellet production by Antarctic krill, Euphausia superba. Mar Biol 98:557-563

Dalley DE, McClatchie S (1989) Functional feeding morphology of the euphausiid Nyctiphanes australis. Mar Biol 101 $195-203$

Drits AV, Semenova TN (1989) Trophic characteristics of major planktonic phytophages from South Shetland Islands region durng early spring. In: Ponomareva LA (ed) Complex investigations of the pelagic zone of the Southern Ocean. Shirsov Institute of Oceanology Publishers, Moscow, p 66-78 (in Russian)

Eppley RW, Reid FMH, Strickland JDH (1970) Estimates of crop size, growth rate, and primary production. Bull Scripps Inst Oceanogr 17:33-42

Everson I, Goss C (1991) Krill fishing activities in the southwestern Atlantic. Antarct Sci 4:351-358

Fransz HG, Gonzalez SR (1995) The production of Oithona similis (Copepoda: Cyclopoida) in the Southern Ocean. ICES J Mar Sci 52:549-555

Fransz HG, Gonzalez SR (1997) Latitudinal metazoan plankton zones in the Antarctic Circumpolar Current along $6^{\circ} \mathrm{W}$ during austral spring 1992. Deep Sea Res 44:395-414

Froneman PW, Pakhomov EA, Perissinotto R, McQuaid CD (1996) Role of microplankton in the diet and daily ration of Antarctic zooplankton species during austral summer. Mar Ecol Prog Ser 143:15-23

Frost BW (1972) Effects of size and concentration of food particles on the feeding behaviour of the marine planktonic copepod Calanus pacificus. Limnol Oceanogr 17:805-815

Gibbons MJ, Barange M, Pillar SC (1991) Vertical migration and feeding of Euphausia lucens (Euphausiacea) in the Southern Benguela. J Plankton Res 13:473-486

Gifford DJ (1993) Consumption of protozoa by copepods feeding on natural microplankton assemblages. In: Kemp PF, Sherr BF, Sherr EB, Cole JJ (eds) Handbook of methods in aquatic microbial ecology. Lewis Publishers, London, p $723-729$

Granéli E, Granéli W, Mozzam Rabbani MM, Daugberg N Fransz G, Cuzin-Roudy J, Alder VA (1993) The influuence of copepod and krill grazing on the species composition of phytoplankton communities from the Scotia-Weddell Sea. Polar Biol 13:201-213

Hamner WM, Hamner PP, Strand SW, Gilmer RW (1983) Behaviour of Antarctic krill, Euphausia superba: chemoreception, feeding, schooling and molting. Science 220 $433-435$

Holm-Hansen O, Huntley ME (1984) Feeding requirements of krill in relation to food sources. J Crustac Biol 4 (Spec No. 1): $156-173$

Hopkins TL (1985) Food web of an Antarctic midwater ecosystem. Mar Biol 89:197-212

Hopkins TL, Ainley DG, Torres JJ, Lancraft TM (1993) Trophic structure in open waters of the marginal ice zone in the Scotia-Weddell confluence region during spring (1983). Polar Biol 13:389-397

Hopkins TL, Torres JJ (1989) Midwater food web in the vicinity of a marginal ice zone in the western Weddell Sea. Deep Sea Res 36:543-560

Huntley ME, Zhou M, Lopez MDG (1994) Calanoides acutus in Gerlache Strait, Antarctica Il. Solving an inverse problem in population dynamics. Deep Sea Res 41:209-227

Ikeda T (1984) Development of the Antarctic krill (Euphausia superba Dana) observed in the laboratory. J Exp Mar Biol Ecol 75:107-117

lkeda T, Dixon P (1982) Body shrinkage as a possible overwintering mechanism of the Antarctic krill, Euphausia superba Dana. J Exp Mar Biol Ecol 62:143-151

Ikeda T, Kirkwood R (1989) Metabolism and body composition of two euphausiids (Euphausia superba and E. crystallorophias) collected under the pack-ice off Enderby Land, Antarctica. Mar Biol 100:301-308

Kils U (1983) Swimming and feeding of Antarctic krill, Euphausia superba-some outstanding energetics and dynamics, some unique morphological details. Ber Polarforsch 4:130-155

Kiørboe T, Saiz E, Viitasalo M (1996) Prey switching behavjour in the planktonic copepod Acartia tonsa. Mar Ecol Prog Ser 143:65-75

Mauchline J (1980) The biology of mysids and euphausiids Adv Mar Biol 18:1-681

McClatchie S (1985) Feeding behaviour of Meganyctiphanes norvegica (M. Sars) (Crustacea: Euphausiacea). J Exp Mar Biol Ecol 86:271-284

Metz C (1996) Life strategies of dominant Antarctic Oithonidae (Cyclopoida, Copepoda) and Oncaeidae (Poecilostomatoida, Copepodal in the Bellingshausen Sea. Ber Polarforsch 207:1-123

Morris DJ, Ward P, Clarke A (1983) Some aspects of feeding in the Antarctic krill, Euphausia superba. Polar Biol 2 $21-26$

Morris DJ, Watkins JL, Ricketts C, Buchholz F, Priddle J (1988) An assessment of the merits of length and weight measurements of Antarctic krill Euphausia superba. Br Antarct Surv Bull 79:27-50

Mullin MM (1969) Production of zooplankton in the ocean the present status and problems. Oceanogr Mar Biol Ann Rev 7:293-310 
Nemoto T (1967) Feeding patterns of euphausiids and differentiations in their body characters. Info Bull Planktol Soc Japan Commem Iss No. 61:157-174

Ohman MD (1984) Omnıvory by Euphausia pacifica: the role of copepod prey. Mar Ecol Prog Ser 19:125-131

Øresland $V$ (1990) Feeding and predation impact of the chaetognath Eukrohnia hamata in Gerlache Strait, Antarctic Peninsula. Mar Ecol Prog Ser 63:201-209

Pakhomov EA, Perissinotto R (1996) Trophodynamics of the hyperiid amphipod Themisto gaudichaudii in the South Georgia region during late austral summer. Mar Ecol Prog Ser 134:91-100

Pakhomov EA, Perissinotto R, Froneman PW, Miller DGM (1997) Energetics and feeding dynamics of Euphausia superba in the South Georgia region durng the summer of 1994. J Plankton Res 19:399-423

Parsons TR, Maita Y, Lalli CM (1984) A manual of chemical and biological methods of seawater analysis. Pergamon, Oxford

Penry DL, Frost BW (1990) Re-evaluation of the gut-fullness (gut fluorescence) method for inferring ingestion rates of suspension feeding copepods. Limnol Oceanogr 35: $1207-1214$

Perissinotto R, Pakhomov EA (1996) Gut evacuation rates and pigment destruction in the Antarctic krill Euphausia superba. Mar Biol 125:47-54

Pilditch CA, McClatchie S (1994) Quantitative analysis of carnivory in the krill Nyctiphanes australis, with an examination of the effect of non-preferred phytoplankton alternative prey. Mar Ecol Prog Ser 107:41-53

Pond DW, Priddle J, Sargent JR, Watkins JL (1995) Laboratory studies of assimilation and egestion of algal lipid by Antarctic krill-methods and initial results. J Exp Mar Biol Ecol 187:253-268

Price HJ (1989) Swimming behaviour of krill in response to algal patches: a mesocosm study. Limnol Oceanogr 34 649-659

Price HJ, Boyd KR, Boyd CM (1988) Omnivorous feeding behaviour of the Antarctic krill Euphausia superba. Mar Biol 97:67-77

Price HJ, Paffenhöfer GA, Strickler JR (1983) Modes of cell capture in calanoid copepods. Limnol Oceanogr 28: $116-123$

Priddle J, Leakey RJG, Symon CJ, Whitehouse MJ, Robins D. Cripps GC, Murphy EJ, Owens NJP (1995) Nutrient cycling by Antarctic marine microbial plankton. Mar Ecol Prog Ser 116:181-198

Priddle J, Whitehouse MJ, Atkinson A, Brierley AS, Murphy EJ (1997) Diurnal changes in near-surface ammonium concentration - interplay between zooplankton and phytoplankton. J Plankton Res 19:1305-1330

Putt M, Stoecker DK (1989) An experimentally determined carbon:volume ratio for marine 'oligotrichous' ciliates

Editorial responsibility: Otto Kinne (Editor),

Oldendorf/Luhe, Germany from estuarine and coastal waters. Limnol Oceanogr 34: $1097-1103$

Quetın LB, Ross RM, Clarke A (1994) Krill energetıcs: sea sonal and environmental aspects of the physiology of Euphausia superba. In: El-Sayed SZ (ed) Southern Ocean ecology. The BIOMASS perspective. Cambridge University Press, Cambridge, p 165-184

Saiz E, Kiørboe T (1995) Predatory and suspension feeding of the copepod Acartia tonsa in turbulent environments. Mar Ecol Prog Ser 122:147-158

Sameoto DD (1980) The relationships between stomach contents and vertical migration in Meganyctiphanes norvegica, Thysanoessa rashii and $T$ inermis (Crustaceana, Euphausiacea). J Plankton Res 2:129-143

Schnack SB (1985) Feeding by Euphausia superba and copepod species in response to varying concentrations of phytoplankton. In: Siegfried WR, Condy PR, Laws RM (eds) Antarctic nutrient cycles and food webs. SpringerVerlag, Berlin, p 311-323

Schnack-Schiel SB, Hagen W, Mizdalski E (1991) Seasonal comparison of Calanoides acutus and Calanus propinquus (Copepoda Calanoida) in the southeastern Weddell Sea, Antarctica. Mar Ecol Prog Ser 70:17-27

Schnack-Schiel SB, Mizdalski E (1994) Seasonal variations in distribution and population structure of Microcalanus pygmaeus and Ctenocalanus citer (Copepoda: Calanoida) in the eastern Weddell Sea, Antarctica. Mar Biol 119 $357-366$

Stoecker DK, Gifford DJ, Putt M (1994) Preservation of marine planktonic ciliates: losses and cell shrinkage during fixation. Mar Ecol Prog Ser 110:293-299

Theilacker GH, Lo NC, Townsend AW (1993) An immunochemical approach to quantifying predation by euphausiids on the early stages of anchovy. Mar Ecol Prog Ser 92: $35-50$

Utermöhl H (1958) Zur Vervollkommnung der quantitativen Phytoplankton-Methodik. Verh Int Verein Limnol 9:1-38

Ward P, Atkinson A, Murray AWA, Wood AG, Williams R, Poulet SA (1995) The summer zooplankton community at South Georgia: biomass, vertical migration and grazing. Polar Biol 15:195-208

Ward P, Atkinson A, Schnack-Schiel SB, Murray AWA (1997) Regional variation in the life cycle of Rhincalanus gigas (Copepoda: Calanoida) in the Atlantic Sector of the Southern Ocean-re-examination of existing data (1928 to 1993). Mar Ecol Prog Ser 157:261-275

Ward P, Shreeve RS (1995) Egg production in three species of Antarctic calanoid copepods during an austral summer. Deep Sea Res 42:721-735

Ward P, Shreeve RS, Cripps GC (1996) Rhincalanus gigas and Calanus similimus: lipid storage patterns of two species of copepod in the seasonally ice-free zone of the Southern Ocean. J Plankton Res 18:1439-1454

Submitted: July 3, 1997; Accepted: October 10, 1997 Proofs recelved from author(s): December 8,1997 